\title{
Chromium Enrichment on P11 Ferritic Steel by Pack Cementation
}

\author{
F. A. Fauzi ${ }^{1, a}$, T. Kurniawan ${ }^{1}$, M. S. Salwani ${ }^{1}$, Y. S. Bin ${ }^{1}$, W. S. W. Harun ${ }^{1}$ \\ ${ }^{1}$ Faculty of Mechanical Engineering, University Malaysia Pahang, 26600 Pekan, Pahang Darul Makmur, Malaysia
}

\begin{abstract}
The future thermal power plant is expected to operate at higher temperature to improve its efficiency and to reduce greenhouse gas emission. This target requires better corrosion properties of ferritic steels, which commonly used as materials for superheater and reheater of boiler tubes. In this work, chromium enrichment on the surface of ferritic steel is studied. The deposited chromium is expected to become a reservoir for the formation of chromia protective layer. Chromium was deposited on the substrate of steel by pack cementation process for two hours at the temperature of $850^{\circ} \mathrm{C}, 950^{\circ} \mathrm{C}$ and $1050^{\circ} \mathrm{C}$, respectively. XRD analysis indicated that chromium was successfully deposited at all temperatures. Somehow, SEM cross sectional image showed that continuous layer of chromium was not continuously formed at $850 \mathrm{oC}$. Therefore, this research clarify that chromium enrichment by pack cementation may be conducted at the temperature above $950^{\circ} \mathrm{C}$.
\end{abstract}

\section{Introduction}

Nowadays, world is facing environmental impact caused by the greenhouse gasses emission from fossil fuel combustion. The awareness of public on global climate change leads to the growing concern on the need to reduce emissions of carbon dioxide and reductions in the range $60-80 \%$ may be needed [1]. The reductions can be done by using low- or zero-carbon energy sources such as renewables energy: wind, hydro and others [2], but for the current stage, fossil fuel power plant is very important in power generation. The fossil fuels that used to generate power included coal, oil and gas mainly covered the energy consumption[3,4]. Therefore, in order to reduce the emissions of greenhouse gases from fossil fuel power plant, increasing thermal efficiency will be one of the solutions [5].

The improvement of thermal efficiency of power plant may be realized by increasing its operating temperature. This condition may lead to more excessive corrosion, especially in boiler components which exposed to high pressure and high temperature steam. Ferritic steel is a common material that used as boiler tubes in superheater and reheater area. Many researchers have reported that oxidation rate of this steel in steam condition was faster that dry atmosphere [6-8]. This is due to retardation of chromium formation and or evaporation of chromia protective layer $[9,10]$. Therefore, improvement of corrosion resistant of this steel is important in order to use this material at higher operating temperature.

In this work, chromium enrichment on ferritic steel is studied by using pack cementation process. This chromium addition is expected to become a reservoir for the formation of chromia protective layer when the steel exposed to high temperature oxidation. This work was objected to study the relation between cementation temperature and homogeneity of chromium diffusion.

\section{Experimental procedure}

\subsection{Sample Preparation}

The sample used for this study is a P11 steel. The samples were cut into small pieces of specimens with the dimensions $10 \times 10 \times 2 \mathrm{~mm}^{3}$ as shown in Figure 1. The surface of specimens were manually polished to a 2000grit-grade finish using $\mathrm{SiC}$ abrasive papers and washed with acetone in an ultrasonic bath to remove its surface rust and greasy dirt.

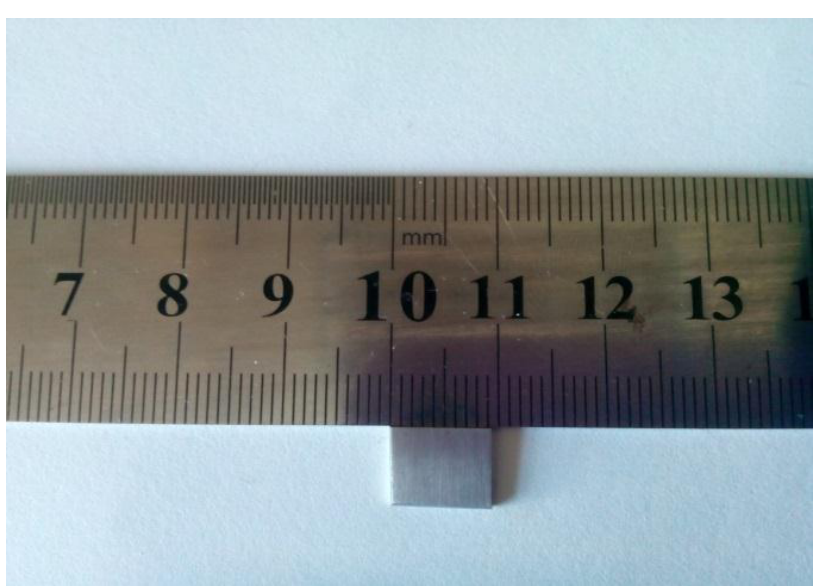

Figure 1: Sample of P11 steel

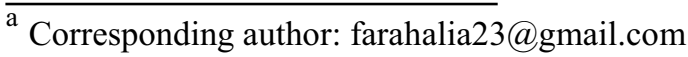


For the pack cementation process, chromium powder as the masteralloy, alumina powder as inert filler and $\mathrm{NH}_{4} \mathrm{Cl}$ as the activator, were mixed homogenously inside ball milling for 30 minutes, according to a predetermined ratio shown in Table 1 . The samples were embedded in the pack mixtures inside alumina crucible and then covered by alumina lid and glued by alumina based cement. The crucible then put into horizontal tube furnace, and loaded with argon gas. The pack cementation was conducted at $850^{\circ} \mathrm{C}, 950^{\circ} \mathrm{C}$, and $1050^{\circ} \mathrm{C}$ for two hours.

Table 1: composition of pack mixtures (wt $\%)$

\begin{tabular}{lllll}
\hline $\mathrm{Cr}$ & $\mathrm{NH}_{4} \mathrm{Cl}$ & $\mathrm{Al}_{2} \mathrm{O}_{3}$ & $\begin{array}{l}\text { Temperature, } \\
{ }^{\circ} \mathrm{C}\end{array}$ & $\begin{array}{l}\text { Time, } \\
\mathrm{h}\end{array}$ \\
\hline 10 & 5 & 85 & 850 & $2 \mathrm{~h}$ \\
10 & 5 & 85 & 950 & $2 \mathrm{~h}$ \\
10 & 5 & 85 & 1050 & $2 \mathrm{~h}$ \\
\hline
\end{tabular}

\subsection{Characterization method}

After the diffusion coating, surface of the samples was investigated with x-ray diffraction (Rigaku Miniflex XRay Diffractometer) with $\mathrm{Cu}-\mathrm{K} \alpha$ radiation in angular range of $10-90^{\circ}$ in $0.010^{\circ}$ steps with $2 \mathrm{~s}$ per step. In addition, the cross section of the samples was investigated by using SEM with EDX (Tabletop SEM TM3030Plus). Before SEM investigation, sample was mounted into epoxy resin and polished by $\mathrm{SiC}$ abrasive paper until 2000-grit continued with diamond paste 0.3 micron, and then cleaned with acetone.

Use A4 paper size $(210 \times 297 \mathrm{~mm})$ and adjust the margins to those shown in Table 1 . The final printed area will be $172 \times 252 \mathrm{~mm}$.

\section{Results and discussions}

Pack cementation of chromium was carried out on P11 at the temperature $850^{\circ} \mathrm{C}, 950^{\circ} \mathrm{C}$ and $1050^{\circ} \mathrm{C}$ to find the suitable condition for the formation of continuous chromium layer. Figure 2 show XRD pattern of each cementation temperature. The star $(*)$ indicator shows the impurities that affected from the carbon that were placed at the holder plate of the samples during the XRD process was running. The peak in the energy spectrum line for element $\mathrm{Cr}$ is clearly different in the three layers. The energy spectrum line peak for element $\mathrm{Cr}$ in the temperature $950^{\circ} \mathrm{C}$ and $1050^{\circ} \mathrm{C}$ has a higher intensity as compared to $850^{\circ} \mathrm{C}$, which may indicate that chromium content or thickness was higher. This result is strengthened by the cross sectional image of the steel from SEM investigation in Figure 3 until 5.

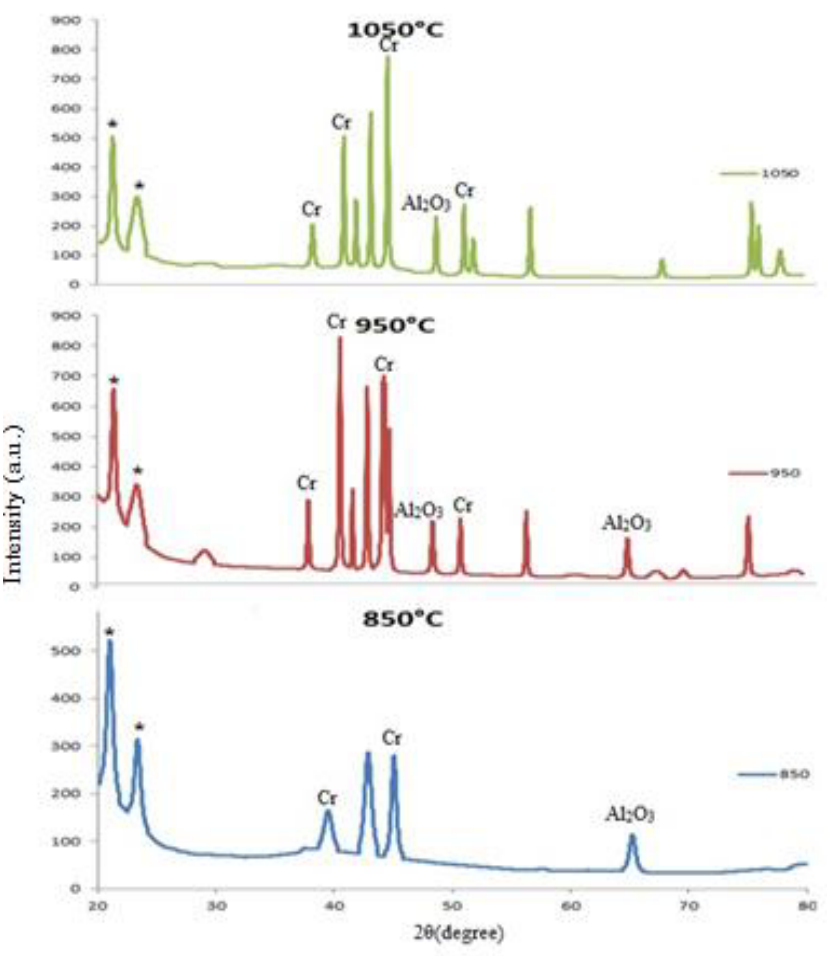

Figure 2: The XRD spectrum for different temperature for pack cementation coating process.

Figure 3 shows the cross sectional image of pack cemented steel at $850^{\circ} \mathrm{C}$. The thickness and formation of the $\mathrm{Cr}$ is not continuous and non-uniform. The inhomogeneity in the oxide will cause the non-uniform distribution of the grain size of $\mathrm{Cr}$ [7]. This first approach using $850^{\circ} \mathrm{C}$ for the deposition of $\mathrm{Cr}$ using pack cementation process show a thin layer of $\mathrm{Cr}$ on top of the steel. Chromizing is generally thin in coating thickness because the pack continues to undergo depletion [11]. We can see from the figures, the thicknesses are very thin, which is less than $1 \mu \mathrm{m}$.

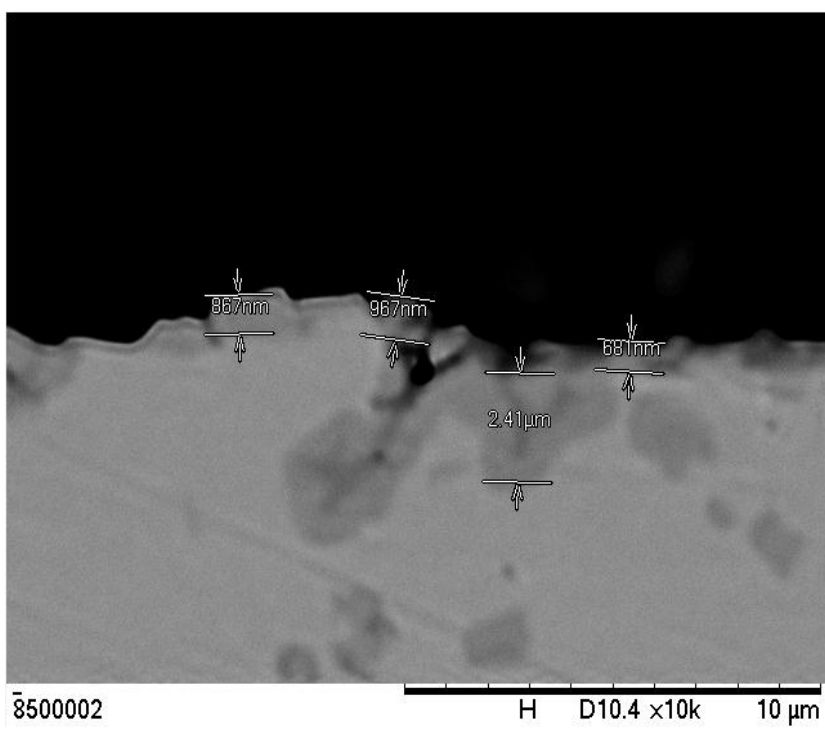

Figure 3: The image of $\mathrm{Cr}$ coating at temperature $850^{\circ} \mathrm{C}$ under BSE-SEM image 
The cross sectional image of pack cemented steel at $950^{\circ} \mathrm{C}$ is shown in Figure 4. The $\mathrm{Cr}$ at this temperature starting to be more continuous and homogenous compare to Figure 3. The thickness of the $\mathrm{Cr}$ is increasing as the increasing in the temperature. The SEM-BSE image shown there are more pores are visible in the diffusion zone. The high activity of activator, chloride at the metal surface the iron in the substrate will react with the halide and cause the evaporation from the substrate. The influence of the pores to the in the diffusion zone soon will be investigated.

The result of pack cementation at temperature $1050^{\circ} \mathrm{C}$ is more likely the same with $950^{\circ} \mathrm{C}$, as it shown in Figure 5 . The chromium thickness at this temperature was slightly thicker due to the more $\mathrm{Cr}$ diffused into the steel.

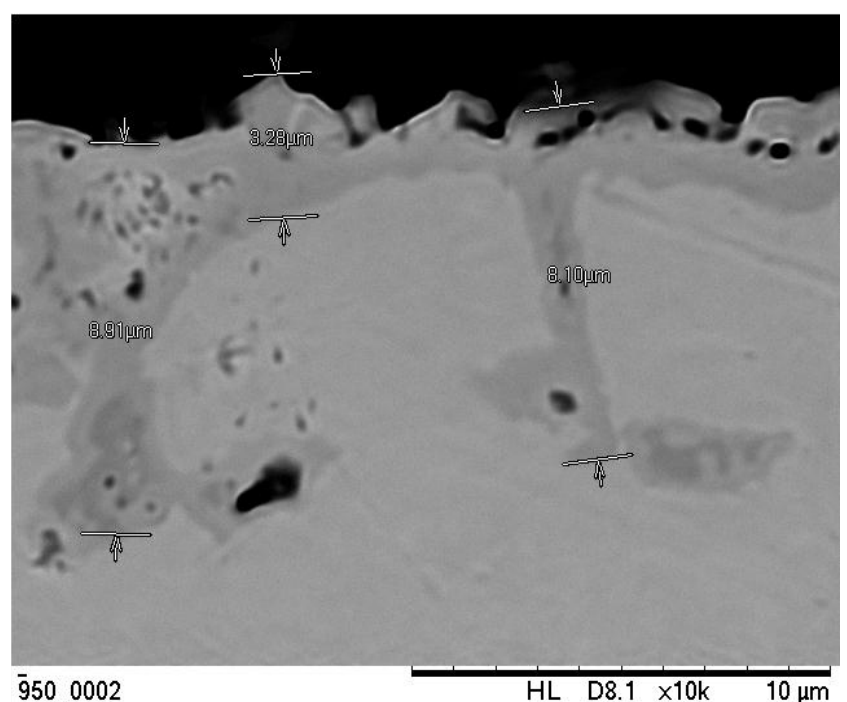

Figure 4: The image of $\mathrm{Cr}$ coating temperature $950^{\circ} \mathrm{C}$ under BSE-SEM image

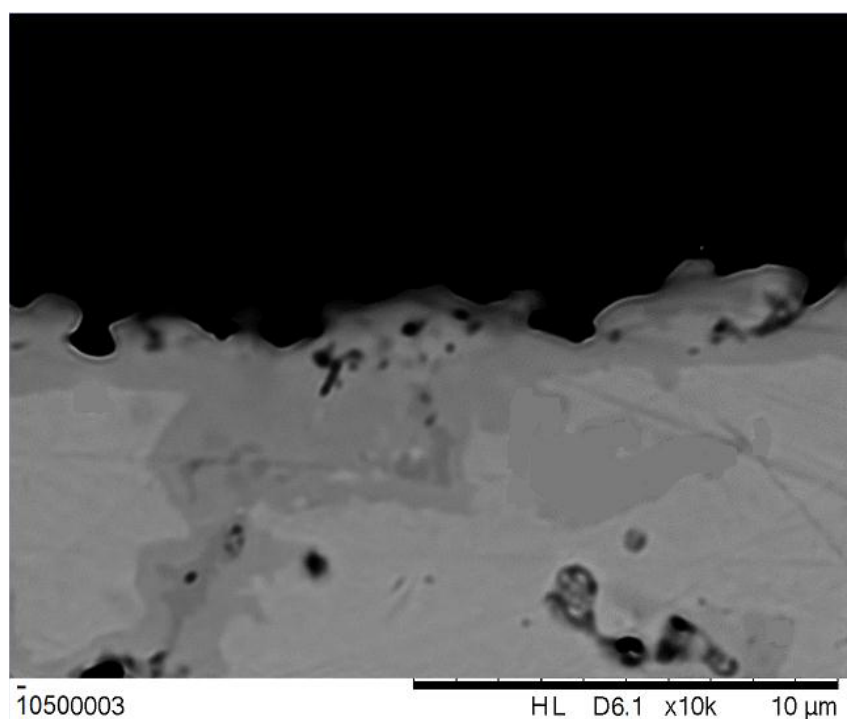

Figure 5: The image of $\mathrm{Cr}$ temperature $1050^{\circ} \mathrm{C}$ under BSESEM image

\section{Conclusions}

Enrichment of chromium on the surface of P11 ferritic steel was conducted by pack cementation process at different temperature, starting from $850^{\circ} \mathrm{C}$ until $1050^{\circ} \mathrm{C}$. From the investigation of cross sectional image by SEM, it was clarified that continuous layer of chromium formed when the enrichment process conducted above $950^{\circ} \mathrm{C}$. This continuous chromium layer is expected to become the reservoir for the formation of chromia protective layer when the steel exposed to boiler environment.

\section{Acknowledgement}

The authors would like to be obliged to Universiti Malaysia Pahang for financial assistance under project RDU140110.

\section{References}

1. van der Hoeven, M., World Energy Outlook 2013. (2013).

2. Jupesta, J. and A. Suwa, Sustainable Energy Policy in Japan, Post Fukushima. Int Assoc Energy Econ Fourth Quart Newsl, (2011). p. 23-26.

3. Viswanathan, R., K. Coleman, and U. Rao, Materials for ultra-supercritical coal-fired power plant boilers. International Journal of Pressure Vessels and Piping, 2006. 83(11): p. 778-783.

4. Holcomb, G.R., et al., Ultra supercritical turbines-steam oxidation. 2004, Albany Research Center (ARC), Albany, OR.

5. Masuyama, F., History of power plants and progress in heat resistant steels. ISIJ international, (2001). 41(6): p. 612-625.

6. Nakai, M., et al., Correlation of high-temperature steam oxidation with hydrogen dissolution in pure iron and ternary high-chromium ferritic steel. ISIJ international, (2005). 45(7): p. 1066-1072.

7. Agüero, A., et al., Oxidation under pure steam: $\mathrm{Cr}$ based protective oxides and coatings. Surface and Coatings Technology, (2013.) 237: p. 30-38.

8. Jacob, Y., et al., The effect of gas composition on the isothermal oxidation behaviour of PM chromium. Corrosion Science, (2002). 44(9): p. 2027-2039.

9. Yang, Z., et al., Effects of water vapor on oxidation behavior of ferritic stainless steels under solid oxide fuel cell interconnect exposure conditions. Solid State Ionics, (2005). 176(17): p. 1495-1503.

10. Ehlers, J., et al., Enhanced oxidation of the $9 \% \mathrm{Cr}$ steel P91 in water vapour containing environments. Corrosion Science,(2006). 48(11): p. 3428-3454.

11. Bose, S., High Temperature Coatings. (2007). 1: p. 73-154. 